\title{
Vegetation exerts a greater control on litter decomposition than climate warming in peatlands
}

\author{
Susan E. Ward, ${ }^{1,3,7}$ Kate H. Orwin, ${ }^{1,2}$ Nicholas J. Ostle, ${ }^{1,3}$ Maria J. I. Briones, ${ }^{3,4}$ Bruce C. Thomson, ${ }^{5}$ \\ Robert I. Griffiths, ${ }^{5}$ Simon OAkley, ${ }^{3}$ Helen Quirk, ${ }^{1}$ and Richard D. Bardgett ${ }^{1,6}$ \\ ${ }^{1}$ Soil and Ecosystem Ecology Laboratory, Lancaster Environment Centre, Lancaster University, Bailrigg, \\ Lancaster LA1 4 YQ United Kingdom \\ ${ }^{2}$ Landcare Research, P.O. Box 40, Lincoln 7640 New Zealand \\ ${ }^{3}$ Centre for Ecology and Hydrology, Lancaster Environment Centre, Library Avenue, Bailrigg, Lancaster LA1 4AP United Kingdom \\ ${ }^{4}$ Departamento de Ecología y Biología Animal, Universidad de Vigo, 36310 Vigo, Spain \\ ${ }^{5}$ Centre for Ecology and Hydrology, Maclean Building, Benson Lane, Wallingford, Oxfordshire OX10 8BB United Kingdom \\ ${ }^{6}$ Faculty of Life Sciences, Michael Smith Building, University of Manchester, Oxford Road, Manchester M139PT United Kingdom
}

Abstract. Historically, slow decomposition rates have resulted in the accumulation of large amounts of carbon in northern peatlands. Both climate warming and vegetation change can alter rates of decomposition, and hence affect rates of atmospheric $\mathrm{CO}_{2}$ exchange, with consequences for climate change feedbacks. Although warming and vegetation change are happening concurrently, little is known about their relative and interactive effects on decomposition processes. To test the effects of warming and vegetation change on decomposition rates, we placed litter of three dominant species (Calluna vulgaris, Eriophorum vaginatum, Hypnum jutlandicum) into a peatland field experiment that combined warming with plant functional group removals, and measured mass loss over two years. To identify potential mechanisms behind effects, we also measured nutrient cycling and soil biota. We found that plant functional group removals exerted a stronger control over short-term litter decomposition than did $\sim 1^{\circ} \mathrm{C}$ warming, and that the plant removal effect depended on litter species identity. Specifically, rates of litter decomposition were faster when shrubs were removed from the plant community, and these effects were strongest for graminoid and bryophyte litter. Plant functional group removals also had strong effects on soil biota and nutrient cycling associated with decomposition, whereby shrub removal had cascading effects on soil fungal community composition, increased enchytraeid abundance, and increased rates of $\mathrm{N}$ mineralization. Our findings demonstrate that, in addition to litter quality, changes in vegetation composition play a significant role in regulating short-term litter decomposition and belowground communities in peatland, and that these impacts can be greater than moderate warming effects. Our findings, albeit from a relatively short-term study, highlight the need to consider both vegetation change and its impacts below ground alongside climatic effects when predicting future decomposition rates and carbon storage in peatlands.

Key words: belowground communities; enchytraeids; litter decomposition; Moor House National Nature Reserve, northern England; open-top chambers; peatland; plant-climate interactions; plant removal; soil invertebrates; soil microbes; vegetation composition; warming.

\section{INTRODUCTION}

Decomposition processes are largely responsible for controlling the rate at which terrestrial carbon returns to the atmosphere, and as such, are integral in determining the carbon storage potential of terrestrial ecosystems. Rates of decomposition are regulated primarily by abiotic conditions, such as temperature and soil moisture. Accordingly, increases in global temperatures are predicted to increase rates of decomposition and release of carbon to the atmosphere, with feedbacks to future global climate warming (Aerts 2006, Bardgett et al. 2008, Craine et al. 2010). Concurrently, terrestrial

Manuscript received 13 February 2014; revised 6 June 2014; accepted 17 June 2014. Corresponding Editor: J. B. Yavitt.

${ }^{7}$ E-mail: s.e.ward@lancaster.ac.uk ecosystems are undergoing significant vegetation change due to factors such as land use (Vitousek et al. 1997, Kareiva et al. 2007), climate change (Walker et al. 2006), and atmospheric nitrogen deposition (Bobbink et al. 2010, Stevens et al. 2010). It is well known that changes in vegetation composition can influence decomposition rates by altering the quality and quantity of litter inputs to soil (Hobbie 1992, Bardgett 2005), and that changes in plant diversity can impact ecosystem processes (Hooper et al. 2005, Cardinale et al. 2012). However, little is known about how changes in live vegetation impact rates of decomposition in the field (but see Jonsson and Wardle (2008)). We also lack an understanding of the importance of vegetation change relative to the direct effects of climate warming and changes in litter species identity, and how these factors 


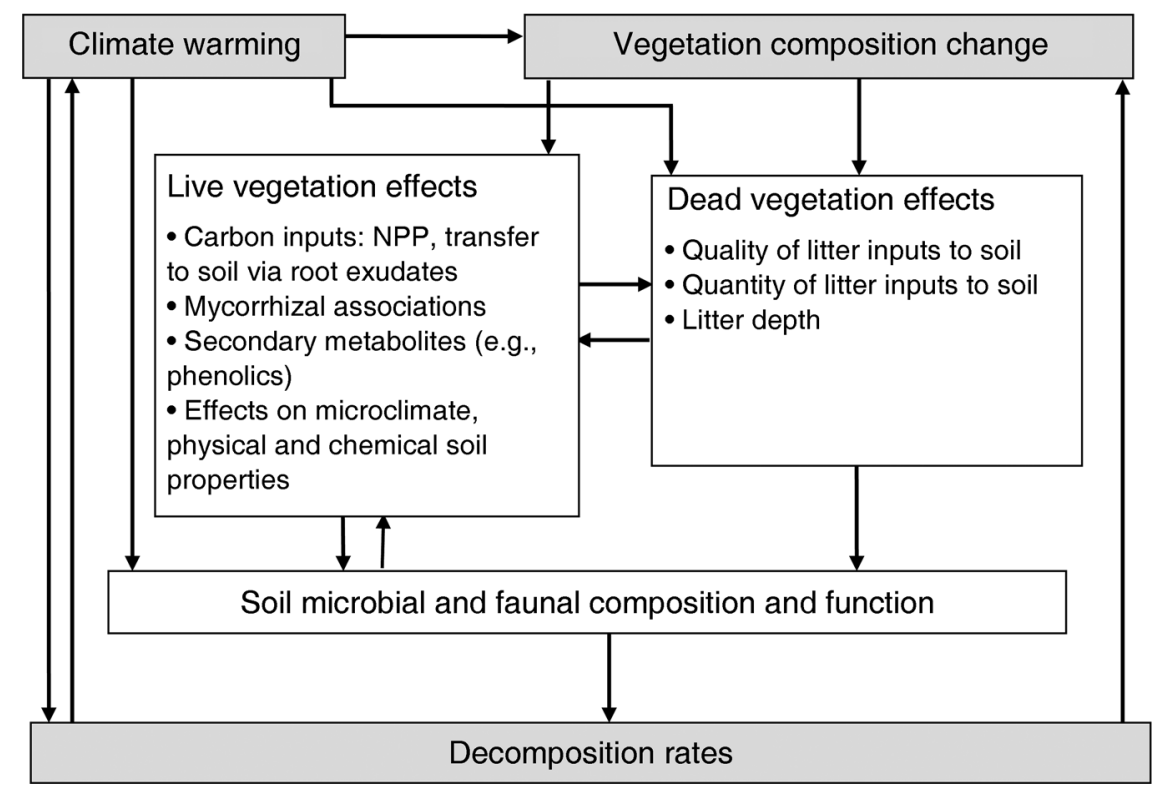

FIG. 1. Influences of climate warming and vegetation change on decomposition processes. Climate warming can affect decomposition both directly and indirectly via changes in vegetation and soil community composition and function. The effects of live and dead vegetation are related to changes in species composition and function, which in turn influence soil biota, with consequences for nutrient availability and subsequent feedbacks to vegetation.

interact. Given that both vegetation change and warming are happening concurrently, this represents a significant gap in our understanding. Such understanding is particularly important for peatlands because of their vulnerability to changes in climate and vegetation, and because of the vast stocks of organic carbon that they contain, estimated to equate to half of the total atmospheric carbon as $\mathrm{CO}_{2}$ (Gorham 1991, Dise 2009). Although previous studies in peatland have shown that warming generally increases rates of decomposition (Bragazza et al. 2009, Carrera et al. 2009, Dorrepaal et al. 2009), and that litter from different plant species decomposes at different rates (Dorrepaal et al. 2007, Ward et al. 2010), we have little understanding of how live vegetation affects decomposition in these carbonrich ecosystems.

Live vegetation effects on decomposition processes operate by influencing soil carbon inputs and the activity and composition of the decomposer community (Bardgett and Wardle 2010), and by altering soil abiotic conditions (Fig. 1). Peatland plant functional groups have been shown to differ in the rate of transfer of recent photoassimilate carbon to soil via their roots, with subsequent effects on the composition and activity of soil biota and carbon cycling processes (Trinder et al. 2008, Ward et al. 2012). Also, it is known that different plant species can promote decomposer communities that are adapted to decomposing their own litter, resulting in a "home-field advantage," whereby litter decomposes faster in soil from its environment of origin (Vivanco and Austin 2008, Ayres et al. 2009). In addition to effects on decomposers, vegetation composition can influence decomposition processes by modifying soil physical and chemical conditions. For example, some plants can alter the $\mathrm{pH}$ and water-holding capacity of soil (Rydin and Jeglum 2006), and others produce high concentrations of polyphenols that are known to have inhibitory effects on microbial decomposition. The influence of live vegetation on decomposition processes via these mechanisms may also interact with differences in litter quality. For example, home-field advantage is expected to be more important for poor-quality litter, and the decomposition of high-quality litter may be less affected by soil nutrient availability than poor-quality litter (Ayres et al. 2009, Freschet et al. 2012). Despite the general assumption that live vegetation composition will influence decomposition rates, few studies have simultaneously linked changes in vegetation community composition, soil organisms, soil nutrient cycling, and litter decomposition rates (Eisenhauer et al. 2013).

There is emerging evidence that warming and vegetation identity interact to affect ecosystem processes. For example, Kardol et al. (2010) showed that vegetation composition can modify the effects of climate on soil enzyme activity and faunal abundance in a grassland ecosystem, and Ward et al. (2013), using the same field experiment as used here, found that the effects of warming on peatland net ecosystem exchange of $\mathrm{CO}_{2}$ were modulated by vegetation composition. Litter decomposition also has been shown to have a speciesspecific response to warming, linked with litter quality (Aerts et al. 2012). Conversely, some studies have detected little or no interactions of vegetation with nutrient additions and other environmental changes on 
soil food webs (Eisenhauer et al. 2013) or litter decomposition (Papanikolaou et al. 2010). However, multifactorial studies remain few, and, to our knowledge, no study has experimentally tested how climate and vegetation composition interact to affect decomposition and soil biota, and whether warming and vegetation effects vary across litter types.

Here, we investigated the relative and interactive effects of warming, live vegetation composition (both functional group composition and richness), and litter identity on peatland decomposition processes and belowground biological communities. This was done using a field-based experiment combining passive warming with plant functional group removals in a peatland ecosystem in northern England (Ward et al. 2013). We tested the following hypotheses: (1) the effect of live vegetation composition on litter decomposition is similar to or stronger than that of $\sim 1^{\circ} \mathrm{C}$ warming; (2) the effects of live vegetation composition and warming on decomposition processes differs with litter species identity (litter quality); and (3) effects of live vegetation composition and warming on decomposition rates can be linked to changes in soil biota and rates of $\mathrm{N}$ cycling. To achieve this, we measured litter mass loss and a range of belowground properties including: microbial community composition; the abundance of enchytraeid worms, which are known to play a key role in decomposition processes in peatland (Briones et al. 1998, Cole et al. 2002); and rates of $\mathrm{N}$ mineralization, a key microbial process regulating soil $\mathrm{N}$ availability.

\section{Materials And Methods}

\section{Study site and experimental design}

The study site is situated in an area of ombrotrophic blanket bog (mean $\mathrm{pH} 4.1)$ at Moor House National Nature Reserve in northern England, UK $\left(54^{\circ} 65^{\prime} \mathrm{N}\right.$, $\left.2^{\circ} 45^{\prime} \mathrm{W}\right)$. Mean annual temperature is $5.8^{\circ} \mathrm{C}$ and mean annual precipitation is $2048 \mathrm{~mm}$ (UK Environmental Change Network; data available online). ${ }^{8}$ Vegetation is classified as Calluna vulgaris-Eriophorum vaginatum blanket mire, Empetrum nigrum ssp. nigrum subcommunity M19b according to the UK National Vegetation Classification, NVC (Rodwell 1991). Vegetation at the site is composed of three main functional groups: ericoid shrubs (dominated by Calluna vulgaris (L.) Hull), graminoids (dominated by the sedge Eriophorum vaginatum L.), and bryophytes/lichens (dominated by Hypnum jutlandicum Holm. and Warncke; Pleurozium schreberi (Brid.) Mitt., and Sphagnum spp.). The mean depth of the peat is $1.2 \mathrm{~m}$, built up since the BorealAtlantic climate transition around $5500 \mathrm{BC}$, with the main peat-forming vegetation being Sphagnum, Eriophorum, and Calluna (Heal and Smith 1978).

We used a field-based experiment, set up in 2008 to test the relative and interactive effects of warming and

${ }^{8}$ http://www.ecn.ac.uk/data vegetation composition (Ward et al. 2013). The experimental design combined passive warming using open-top chambers (OTCs) with vegetation change using a plant removal approach (Diaz et al. 2003, Wardle and Zackrisson 2005). The use of selective plant removals allowed us to measure the effects on belowground properties of each plant functional group in situ and thereby assess how vegetation change in response to global change drivers (e.g., nitrogen deposition, land use change, climate change) might impact ecological processes. The plant functional group manipulations were from the three dominant vegetation types present: ericoid shrubs (S), graminoids (G), and bryophytes/lichens (B). Vegetation removals were undertaken from areas measuring $1.5 \times 1.5 \mathrm{~m}$, by carefully clipping the shoots of vascular plants to ground level and removing all green photosynthetic bryophyte and lichen tissues. We created fully factorial combinations of the three plant functional groups, to give eight different treatments: a control with all vegetation present, three single groups $(\mathrm{S}, \mathrm{G}$, or $\mathrm{B})$, three double groups $(S+G, S+B, G+B)$, and a treatment in which all aboveground vegetation was removed. Experimental plots were then left to settle for a year to minimize the side effects of decomposition from roots and vegetation, and removal treatments were maintained by regular visits. Despite this period of stabilization, our results relating to effects of plant functional group removal should be taken with some caution, given that the experiment reported here probably commenced before the system had reached a new stable state.

The experimental design consisted of four blocks, containing randomly arranged warmed and nonwarmed replicates of each of the eight plant function type combinations $(n=64)$ (Ward et al. 2013). Warming was applied to half of the experimental plots using OTCs (Marion et al. 1997, Ward et al. 2013). Although these warming chambers have limitations, most notably the potential for side effects on temperature and hydrology (Marion et al. 1997, Bokhorst et al. 2011), they provide a valid and robust method for quantitatively comparing the effect of warming in a remote field situation. Air temperatures were recorded at vegetation canopy height by electronic loggers. Warming from the OTCs increased the mean midday air temperatures by $\sim 1{ }^{\circ} \mathrm{C}$, (Ward et al. 2013). The plant removal treatments also influenced mean growing-season air temperatures over the same period, with shrub removal increasing mean temperatures by $0.2^{\circ} \mathrm{C}$, and graminoid removal decreasing temperatures by $0.2^{\circ} \mathrm{C}$. Water table depth was measured manually from $1 \mathrm{~m}$ length dip-wells installed in each of the experimental plots. Mean annual water table depth was $6.6 \mathrm{~cm}$ below the surface, but neither warming from the OTCs nor plant removal treatments had any detectable effect on water table drawdown (Ward et al. 2013). 


\section{Litter decomposition}

Rates of litter decomposition were determined by measuring mass loss of litter bags. Three types of litter were used, representing the most common species for each of the three dominant plant functional groups, namely Calluna vulgaris (ericoid shrubs), Eriophorum vaginatum (graminoids), and Hypnum jutlandicum (bryophytes), referred to as Calluna, Eriophorum, and Hypnum hereafter. This gave a representative range of litter quality in terms of $\mathrm{C}: \mathrm{N}$ ratios, with the greatest litter quality being for graminoids, and the lowest for bryophytes (Dorrepaal et al. 2007). Litter was collected from undisturbed areas at the field site. Litter bags $(5 \times 5$ $\mathrm{cm}$ ) containing $0.5 \mathrm{~g}$ air-dried litter from each of the individual plant functional groups were assembled from 1-mm PVC/glass mesh, lined on the underside with an additional layer of finer polyester $250-\mu \mathrm{m}$ mesh. This allowed the colonization by the dominant soil mesofauna, including small invertebrates such as enchytraeids (terrestrial oligochaetes) and insect larvae, while preventing finer litter from dropping through the bottom. Two sets of litter bags were placed in each field plot at the base of the litter layer, in contact with the top of the peat organic horizon. An additional three repetitions of each litter bag type were transported to the field to ascertain how much litter was lost in transit. Subsamples of litter were oven-dried at $60^{\circ} \mathrm{C}$ to obtain dry mass, and the final litter mass loss figures were adjusted to take into account both litter lost in transit and differences between air-dried and final oven-dried mass.

Litter bags were recovered in spring 2010 and 2011, i.e., after one and two years of incubation in the field, and were stored in the laboratory at $4^{\circ} \mathrm{C}$ until processed. Large roots and soil particles were removed from the outside of the recovered litter bags, which were then carefully rinsed with deionized water. Litter bags were then cut open and the contents sorted to remove any remaining roots and soil using forceps. Cleaned litter was dried at $60^{\circ} \mathrm{C}$ and reweighed.

\section{Soil properties}

Soil samples were taken from all plots in the middle of the growing season in summer 2010, between the first and second year of litter sampling. To determine treatment effects on the abundance of the dominant soil mesofauna of peatland, we measured the abundance of enchytraeid worms and Diptera larvae. For mesofaunal extractions, samples consisted of intact soil cores, $64 \mathrm{~mm}$ in diameter and $10 \mathrm{~cm}$ long, collected in August 2010. Each core was placed separately in a plastic bag and transported to the laboratory in a cool box. Enchytraeids and Diptera larvae were extracted within $48 \mathrm{~h}$ using a modified wet-funnel method (O'Connor 1955), preserved in $70 \%$ ethanol, and individually counted.

For microbial community analysis and $\mathrm{N}$ mineralization, soil cores, measuring $3 \mathrm{~cm}$ in diameter and $10 \mathrm{~cm}$ deep, were removed from each field plot, stored in polythene bags at $4^{\circ} \mathrm{C}$, and then hand-sorted to remove any root material. Samples were analyzed for potential $\mathrm{N}$ mineralization using potassium chloride $(\mathrm{KCl})$ extractions (Ward et al. 2007). Briefly, fresh soil samples were mixed with $1 \mathrm{~mol} / \mathrm{L} \mathrm{KCl}$ on an orbital shaker (model KS501 digital, IKA, Werke, Germany) and then filtered. Concentrations of $\mathrm{NH}_{4}-\mathrm{N}$ and $\mathrm{NO}_{3}-\mathrm{N}$ in filtrate were determined by colorimetric technique (Ross 1992), on a continuous-flow stream autoanalyzer (Autoanalyzer 3, Bran Luebbe, Norderstedt, Germany). A second set of samples were incubated at $25^{\circ} \mathrm{C}$ for 14 days, extracted, and analyzed as for the first set. Potential rates of $\mathrm{N}$ mineralization were then calculated as the difference between incubated and non-incubated samples, to give an indication of soil $\mathrm{N}$ availability.

Effects of warming and vegetation on bacterial and fungal community structure were assessed using a terminal restriction fragment length polymorphism ( $\mathrm{T}$ RFLP) method. Total nucleic acids were extracted from $0.25 \mathrm{~g}$ fresh mass of soil according to the method described by Griffiths et al. (2000), including an additional freeze-thaw step to aid lysis of cells. Bacterial and fungal communities were analyzed using fluorescently labeled primer pairs 63F and 519r (Lane 1991, Marchesi et al. 1998), and ITS1F and ITS4 (White et al. 1990, Gardes and Bruns 1993), respectively. Restriction endonuclease digestions were then carried out with Msp 1 and Taq 1 prior to T-RFLP analysis (Thomson et al. 2010). The relative abundance of individual T-RFs was calculated by dividing the intensity of each fragment by the totaled intensity of all fragments, and changes in microbial communities were assessed using multivariate statistical approaches based on between-sample BrayCurtis dissimilarities.

\section{Data analysis}

Data were checked for normality using the residualplots method, and were log-transformed where necessary before analysis. The effects and interactions of experimental warming, vegetation composition, and litter species identity on litter decomposition and belowground properties were analyzed by ANOVA, using SAS Enterprise Guide 4.3 and SAS version 9.0 (SAS Institute, Cary, North Carolina, USA). Live vegetation effects were analyzed as the presence or absence of shrubs, graminoids, and bryophytes. The effects of vegetation diversity were also analyzed, based on the number of plant functional groups present (i.e., 0-3). After confirming significant differences in decomposition between litter species identity, litter mass loss data were also analyzed separately by litter species to obtain a deeper understanding of results. Statistical analyses of soil microbial communities were performed with the vegan library (Oksanen et al. 2013) of the R software package version 3.0.2 ( $\mathrm{R}$ Development Core Team 2013). Briefly, a Bray-Curtis distance matrix of between-sample dissimilarities was calculated and subsequently represented through two-dimensional nonmet- 
ric multidimensional scaling (NMDS), using the metaMDS function. Differences in soil microbial communities were quantified by permutational multivariate analysis of variance (PERMANOVA) using the adonis function, and changes in between-sample variance (beta diversity) were quantitatively assessed using the betadisper function.

\section{RESULTS}

\section{Litter decomposition}

In year one, mean litter mass loss decreased in the order Eriophorum $>$ Calluna $>$ Hypnum (Table 1). Litter species identity was the strongest driver of decomposition rate $\left(F_{2,187}=42.9, P<0.0001\right)$ (see Appendix A), with all three litter species differing significantly from each other. In contrast, warming and live vegetation composition had no detectable effect on litter mass loss in year one. Litter species identity was also significant in year two, where rates of decomposition for Eriophorum litter were greater than for Calluna litter $\left(F_{2,189}=3.1, P=0.05\right)$, but stronger effects on decomposition were observed as a result of the composition of live vegetation, i.e., the presence or absence of the three plant functional groups in the plots in which the litter bags were buried. Specifically, mean litter decomposition rates increased when shrubs were removed from the vegetation community $\left(F_{1,189}=12.9\right.$, $P=0.0004$ ), but no such effect was observed after removal of graminoids $\left(F_{1,189}=2.2, P=0.14\right)$ or bryophytes $\left(F_{1,189}=1.5, P=0.22\right)$.

When the three litter species were considered individually (Fig. 2), we found that shrub removal resulted in higher decomposition rates of both Eriophorum (by $9 \%$; $F_{1,63}=6.9, P=0.01$ ) and Hypnum (by $14 \% ; F_{1,63}=4.7, P$ $=0.04)$ in year two, whereas decomposition rates of Calluna litter were not strongly affected $\left(F_{1,63}=2.9, P=\right.$ $0.10)$. In year one, rates of Hypnum litter decomposition were increased by $20 \%$ when bryophytes were removed from the vegetation community $\left(F_{1,63}=4.7, P=0.03\right)$. Vegetation diversity, i.e., the number of live plant functional groups present in the experimental plots, had no detectable effect on litter decomposition in either year $\left(F_{1,376}=0.8, P=0.52\right)$ (see Appendix B).

The effect of experimental warming on litter decomposition was much weaker than the effects of either litter identity or live vegetation composition, with no significant warming effects in year one. In year two, we observed an interaction between the effect of warming and live vegetation composition $\left(F_{1,189}=3.9, P=0.05\right)$, whereby warming increased mean litter decomposition from $34.4 \%$ to $37.7 \%$ in the presence of shrubs. In contrast, when shrubs were removed, there was no significant difference in mean rates of decomposition (40.5\% without warming and $39.7 \%$ with warming). However, when data were analyzed by individual litter species, we found no significant effects of warming on any litter type, and no interactions between warming
TABLE 1. Effects of experimental warming on litter mass loss (mean $\pm \mathrm{SE}$ ) in year 1 and year 2 in a blanket bog at Moor House National Nature Reserve, northern England.

\begin{tabular}{llc}
\hline \hline & \multicolumn{2}{c}{ Litter mass loss (\%) } \\
\cline { 2 - 3 } Litter type, by year & Non-warmed & Warmed \\
\hline Year 1 & & \\
$\quad$ Calluna litter & $20.4 \pm 0.8$ & $20.1 \pm 0.7$ \\
$\quad$ Eriophorum litter & $25.5 \pm 1.5$ & $25.6 \pm 0.9$ \\
Hypnum litter & $16.4 \pm 1.1$ & $15.7 \pm 1.0$ \\
Year 2 & & \\
Calluna litter & $36.5 \pm 1.3$ & $36.1 \pm 1.0$ \\
$\quad$ Eriophorum litter & $38.6 \pm 1.0$ & $40.7 \pm 1.3$ \\
Hypnum litter & $37.5 \pm 2.1$ & $39.4 \pm 1.7$ \\
\hline
\end{tabular}

and litter type and warming with vegetation composition.

\section{Soil properties}

The effects of vegetation community composition and warming on soil biota were dependent on the identity of the mesofauna and microbes, but overall, the effects of vegetation were stronger than those of experimental warming (see Appendix C). For enchytraeids, the removal of shrubs increased their abundance by $131 \%$ (Fig. 3d), although this response was only weakly significant $\left(F_{1,64}=3.6, P=0.06\right)$. There was also a weak interaction between warming and graminoid removal $\left(F_{1,64}=3.8, P=0.06\right)$, with warming increasing enchytraeid abundance when graminoids were present by $26 \%$, and decreasing it by $41 \%$ when graminoids were absent. In contrast, the abundance of Diptera larvae did not significantly change with vegetation removal (Fig. 3e). No effects of vegetation diversity, measured as the number of live plant functional groups present, were detected for either enchytraeid or dipteran population numbers. Warming had a detrimental effect on the abundance of soil fauna (Fig. 3a, b). The abundance of enchytraeids declined by $18 \%$ with warming, although this response was only weakly significant $\left(F_{1,64}=3.4, P\right.$ $=0.07)$. The response of Diptera larvae was much stronger $\left(F_{1,64}=4.8, P=0.03\right)$, with a $45 \%$ decrease in abundance in warmed relative to ambient treatments.

Bacteria and fungi also responded differently to the warming and vegetation treatments, with fungal communities being altered by the removal of shrubs $\left(F_{1,64}=\right.$ 2.7, $P=0.001$; Fig. 4a), whereas bacterial communities were unaffected by the vegetation treatments. No effect of plant species diversity (number of live plant functional types) was detected for either fungi or bacteria. Warming significantly affected bacterial community structure $\left(F_{1,64}=2.2, P=0.045\right.$; Fig. $\left.4 \mathrm{~b}\right)$, but not fungal communities. No interactions were detected between vegetation composition and warming with respect to microbial community composition (see Appendix C).

Potential rates of $\mathrm{N}$ mineralization in soil were affected by the removal of vascular plants, with $35 \%$ 
Year 1
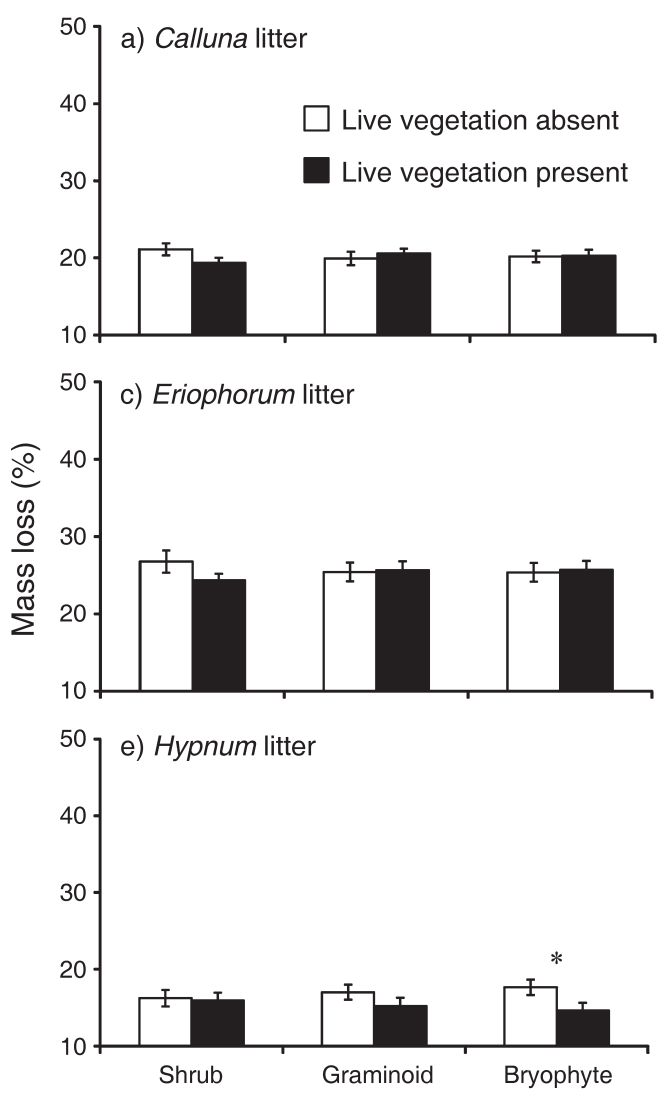

Year 2

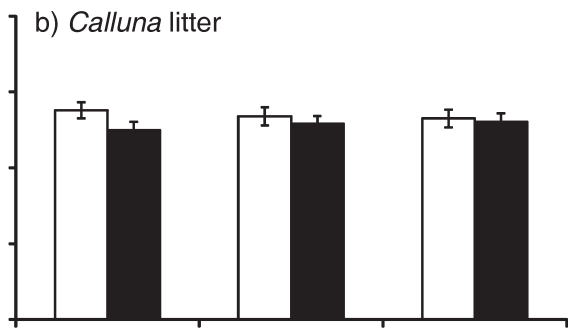

d) Eriophorum litter
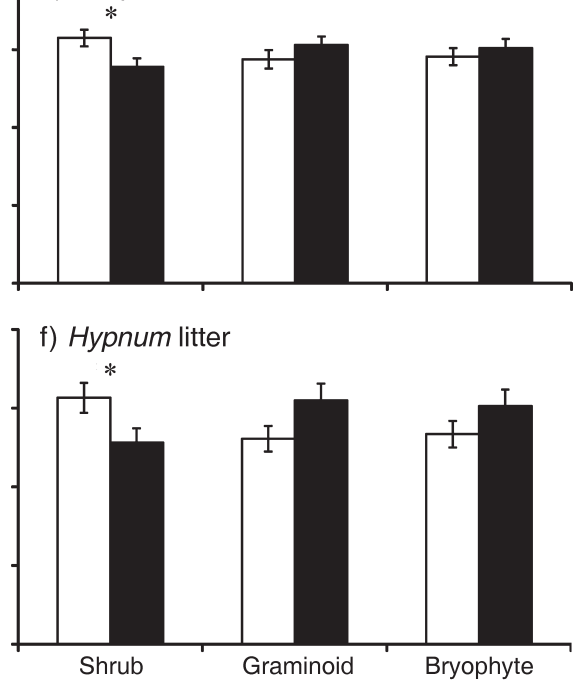

Live vegetation in field plots

FIG. 2. Litter bag mass loss (mean \pm SE) for Calluna, Eriophorum, and Hypnum litter after one year (left-hand column) and two years (right-hand column), shown for the absence (open bars) and presence (black bars) of the three live plant functional groups in field incubation plots at a blanket bog in Moor House National Nature Reserve, northern England. Significant differences $(P<0.05)$ between the presence and absence of live plant functional groups shown by a single asterisk.

and $40 \%$ greater rates of $\mathrm{N}$ mineralization after removal of shrubs and graminoids, respectively (Fig. 3f). A reduction in vegetation diversity from two to one or no plant functional groups present also increased rates of $\mathrm{N}$ mineralization $\left(F_{3,64}=3.4, P=0.03\right)$. However, no effect of warming on rates of $\mathrm{N}$ mineralization was detected (Fig. 3c), and there were no significant interactions between warming and vegetation composition.

\section{DisCUSSION}

The aim of our study was to examine the relative and interactive effects of warming, vegetation composition, and litter identity on decomposition processes in a peatland ecosystem. As hypothesized, vegetation removal exerted stronger controls over litter decomposition than did a $1^{\circ} \mathrm{C}$ experimental warming. These effects were mediated by both litter quality and live plant effects, and were associated with changes in belowground communities and rates of $\mathrm{N}$ mineralization. Our study was conducted over a relatively short time period of two years, and the experimental vegetation removal created more extreme vegetation change than would be expected from current global change. Nevertheless, our findings reveal in situ the influential role of both live and dead vegetation composition as a driver of peatland decomposition processes.

As anticipated, litter decomposition was strongly influenced by litter species identity, with the greatest effects being observed after the first year of incubation, when mass loss was greatest for Eriophorum and least for Hypnum litter, which was probably due to differences in litter quality (Dorrepaal et al. 2007, Ward et al. 2010). After two years of decomposition, litter identity effects, although still significant, were weaker and live vegetation played a much more significant role. Together, these findings suggest that litter decomposition is driven more strongly by the effects of litter identity during the first year of decomposition, when there is a greater availability of labile substrates in decaying litter, and that live plant effects may become more important during subsequent stages of litter decomposition. Conclusions regarding long-term $\mathrm{C}$ accumulation from short-term decomposition studies need to be treated with caution, due to varying rates of litter mass loss over 

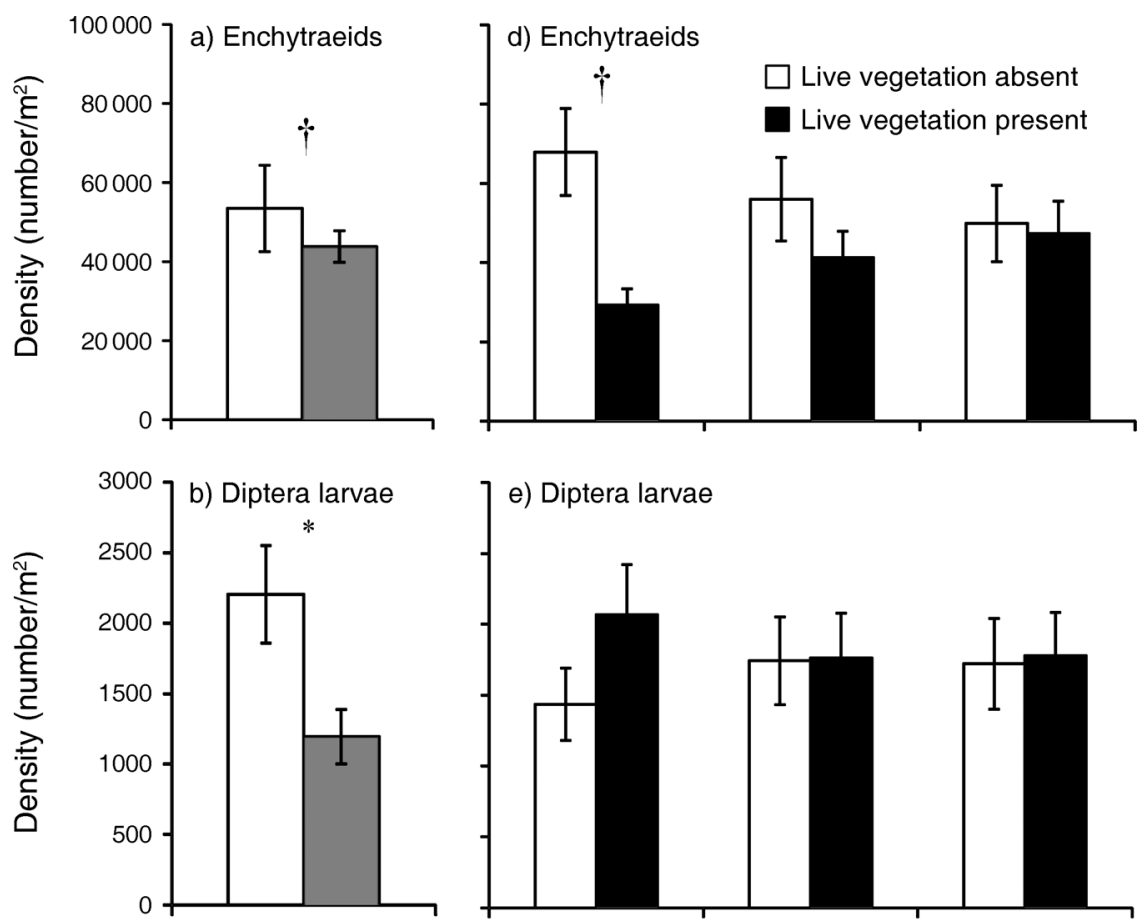

e) Diptera larvae
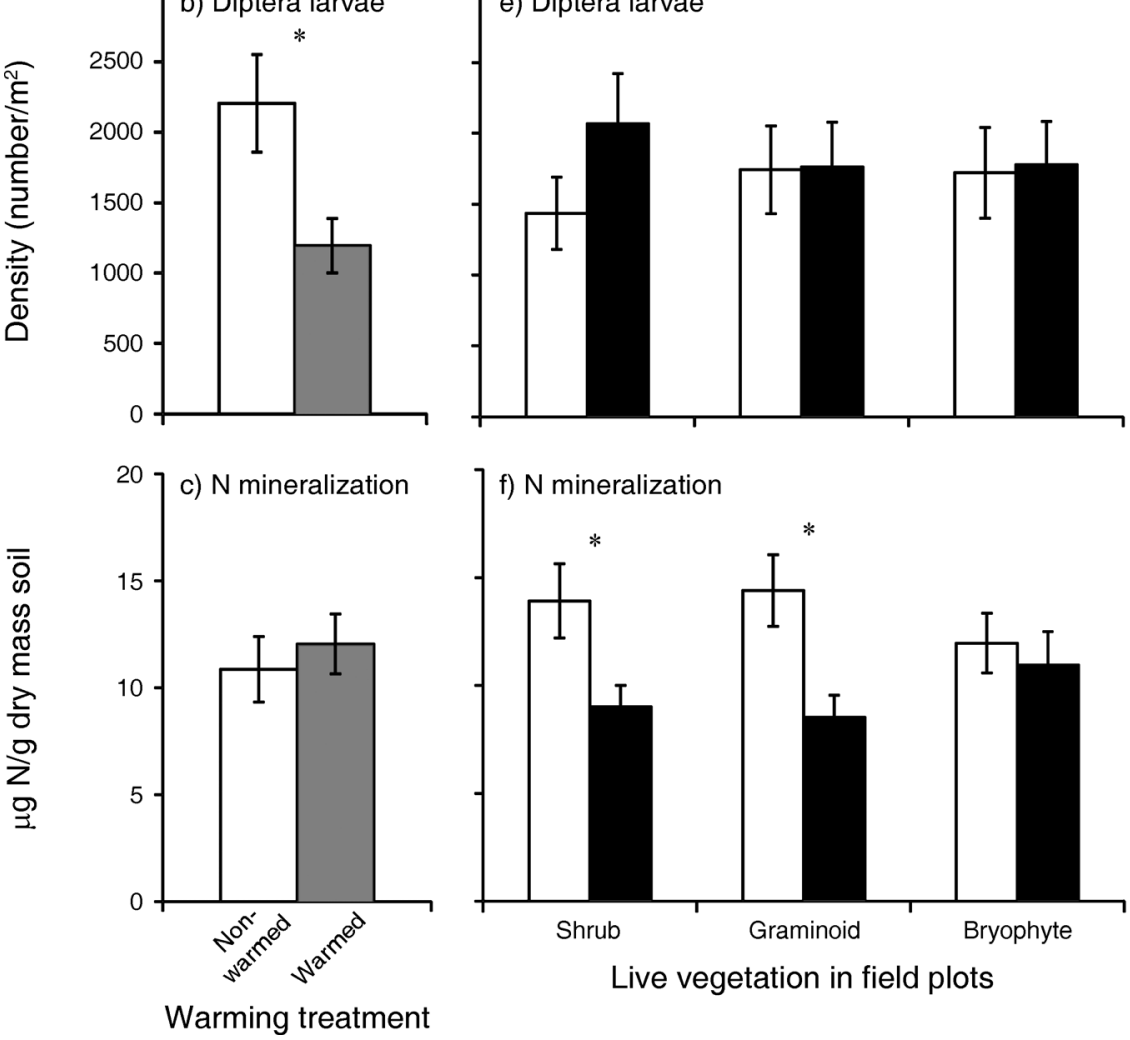

FIG. 3. Effects of warming (left-hand column) and effects of the presence and absence of the three live plant functional groups in field incubation plots (right-hand column) on (a, d) enchytraeid density, (b, e) Diptera larvae density, and (c, f) N mineralization potential. Values are mean \pm SE. Significant differences $(P<0.05)$ between non-warmed and warmed and between the presence and absence of live plant functional groups are indicated by a single asterisk; the dagger indicates differences at $P<0.10$.

longer timescales (Latter et al. 1998). Nevertheless, our results highlight that both live plant and litter effects should be taken into account when considering how vegetation change impacts decomposition rates, at least in the short term.

The greatest effect of live plants on litter decomposition rates was due to plant functional group composition, with no effect of functional group richness. More specifically, rates of litter decomposition were greater in the absence of shrubs, with the strongest effects seen for Eriophorum and Hypnum litter. This finding is consistent with Jonsson and Wardle (2008), who found similar positive effects of ericoid shrub removal on decompo- sition rates in a boreal forest system. Several mechanisms could have contributed to the slower rates of litter decomposition in the presence of ericoid shrubs. First, shrubs typically produce large concentrations of highmolecular-weight polyphenolic compounds, which are known to inhibit microbial activities and nutrient cycling (Hattenschwiler and Vitousek 2000, Fenner and Freeman 2011). The accumulation of phenolic compounds in peatlands suppresses the activity of hydrolase enzymes, which in turn reduces peat decomposition through the enzymatic latch mechanism (Freeman et al. 2001). Second, the association of ericoid shrubs with mycorrhizal fungi might have contributed to 
a) Soil fungi

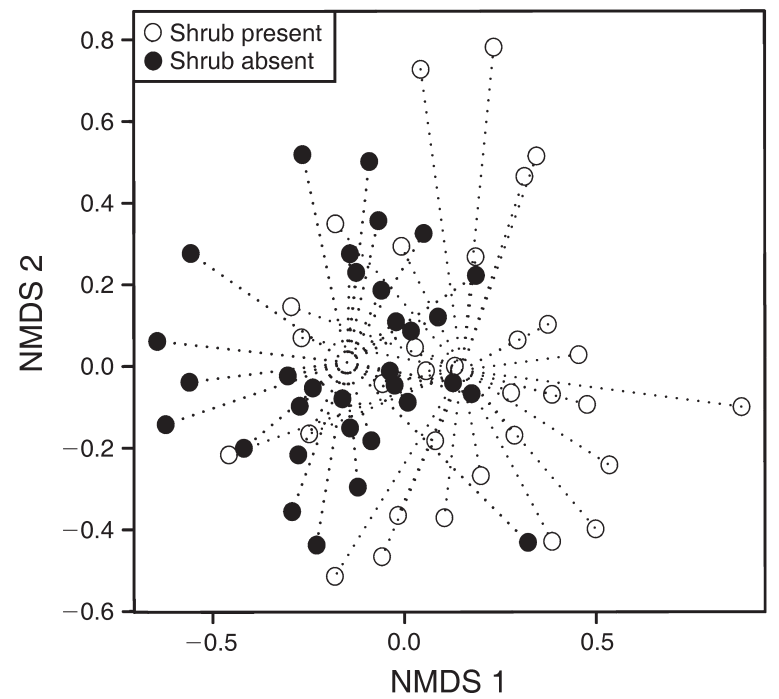

b) Soil bacteria

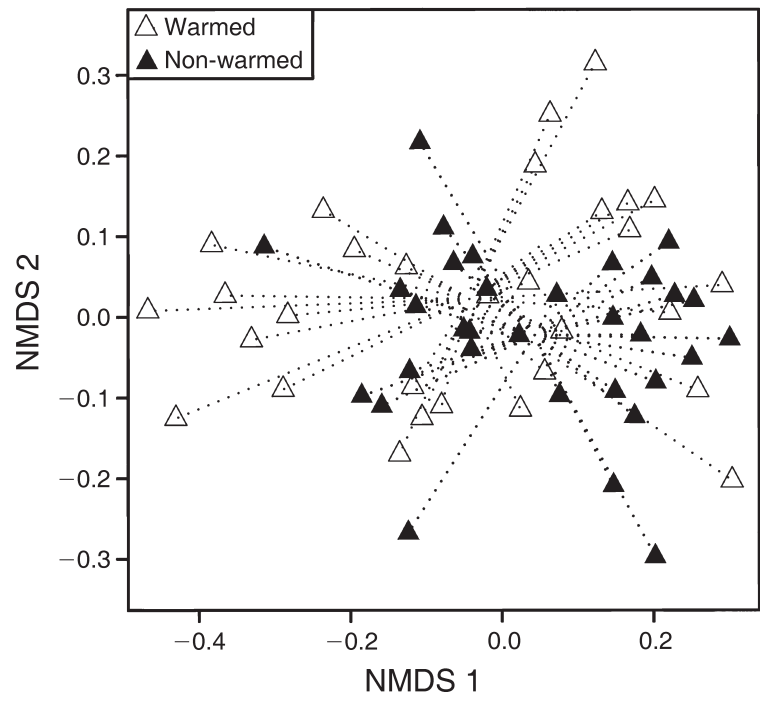

FIG. 4. Two-dimensional NMDS (nonmetric multidimensional scaling) ordination analysis of T-RFLP (terminal restriction fragment length polymorphism) data for (a) soil fungi from plots with and without live shrubs; and (b) soil bacteria from warmed and non-warmed plots. Fungal communities from plots with and without shrubs are depicted by open and closed circles, respectively. Differences in bacterial communities between warmed and non-warmed soils are depicted by solid and open triangles, respectively.

the slower rates of litter decomposition in the presence of shrubs. Ericoid mycorrhizal fungi produce enzymes that allow direct uptake of organic nutrients from complex substrates (Read and Perez-Moreno 2003, Read et al. 2004). This may result in higher soil C:N ratios, which reduces nitrogen availability for saprotrophic decomposers and, subsequently, can decrease decomposition rates (Read et al. 2004, Orwin et al. 2011, Averill et al. 2014). Finally, shrub removal increased air temperatures at the canopy level, which was probably due to the loss of the dense shrub canopy and its effects on evapotranspiration and shade levels (Grace and Marks 1978). This increase in temperature, in turn, could have contributed to the greater rates of decomposition with shrub removal. However, no change in decomposition was detected from the reduction in air temperature caused by the removal of graminoids.

Our results, and those of previous studies at the same site (Ward et al. 2013), suggest that changes in nutrient availability were linked to the enhanced litter decomposition seen with shrub removal. Evidence for this comes from the finding that shrub removal was associated with an increase in potential $\mathrm{N}$ mineralization, albeit at a single sampling point. In addition, shrub removal resulted in higher DOC, DON, and microbial biomass C:N (Ward et al. 2013), which suggests increased biological activity in the soil. We also found that enchytraeids, which are the most dominant fauna in terms of biomass and function in peatland systems (Briones et al. 2007), increased weakly in response to shrub removal. Given the importance of enchytraeids in promoting DOC and DON production, and accelerating rates of $\mathrm{C}$ and $\mathrm{N}$ mineral- ization (Briones et al. 1998, Cole et al. 2002, Carrera et al. 2009), their positive response to shrub removal is likely to have contributed to the observed increases in litter decomposition. Taken together, our results point to a cascade of effects of shrub removal on the soil system that promote rates of litter decomposition (Bragazza et al. 2013), illustrating the importance of live plant effects on decomposition through soil processes.

Graminoid and bryophyte removal had remarkably few effects on decomposition and soil properties. This result was unexpected for bryophytes, because members of this functional group, particularly Sphagnum mosses, are known to play an important role in controlling rates of decomposition and carbon cycling (Lindsay 2010). It is, however, consistent with Orwin and Ostle (2012), who also found that the presence of bryophytes did not alter in situ decomposition rates compared to bare ground. The lack of a detectable bryophyte effect here may be because Sphagnum mosses, although present in our system, were not the dominant bryophyte.

As hypothesized, we found that the influence of the plant removal treatments on litter decomposition interacted with litter identity. Shrub removal resulted in increased rates of decomposition for Eriophorum and Hypnum, but only a weak increase for Calluna litter, suggesting at least some "home-field advantage" for shrubs. To test this hypothesis, we calculated a home-field advantage index (Ayres et al. 2009), using year two mean litter mass loss data within each block for the presence and absence of shrubs, graminoids, and bryophytes. A significant difference in home-field advantage was detected between the Calluna and Hypnum litter $\left(F_{2,12}=5.6, P\right.$ 
$=0.04$ ), with Calluna litter showing a positive home-field advantage (index value 5.4), compared with a home-field disadvantage for both Eriophorum (-1.2) and Hypnum (-3.7) litter. A home-field advantage has been widely attributed to differences in decomposer communities, and could be related to the differences observed in fungal communities after shrub removal in our study. However, many uncertainties still remain over the home-field advantage effect (Vivanco and Austin 2008, Ayres et al. 2009, St John et al. 2011), and to our knowledge, no studies have yet tested its effect on long-term decomposition at different stages of the decomposition continuum. Nevertheless, our study indicates that home-field advantage may play a role in driving decomposition in peatland ecosystems, and highlights the interactions among live plants, soil biota, and litter types.

The overall lack of consistent warming effects on litter decomposition most likely reflects the generally slow rates of long-term carbon cycling processes in peatlands, and the relatively short time period of this study (Rinnan et al. 2007, Aerts et al. 2012, Weedon et al. 2012). Effects of warming were detected in belowground communities, although responses differed across components of the soil food web. Specifically, we found that bacterial community composition responded to warming, but not vegetation composition, whereas for the fungal community the opposite was found, highlighting the differing responses of these two main components of the microbial decomposer community. This suggests that bacteria, which are typically associated with faster rates of nutrient cycling than fungi (Wardle et al. 2004, de Vries et al. 2013), are more likely to influence any future responses of decomposition to temperature. In contrast, fungi which play a dominant functional role in acidic, nutrient-poor systems (Thormann 2006), are more likely to mediate effects of vegetation change on decomposition in these systems. We also detected detrimental effects of warming on soil fauna, especially Diptera larvae, which other studies have also found to respond negatively to climate change (Briones et al. 1997, Pearce-Higgins 2010). As such, their populations could be dramatically reduced at higher temperatures with cascading effects on the soil food chain (Buchanan et al. 2006). The observed reduction in enchytraeid abundance due to warming was only weakly significant, possibly because the temperature increase of $1{ }^{\circ} \mathrm{C}$ was insufficient to alter soil moisture conditions (Ward et al. 2013) or to strongly affect population sizes and vertical distribution of the enchytraeids (Briones et al. 1997). Although no effects of warming were detected on individual litter species decomposition, the mean litter decomposition rate for all litter types combined was faster in the presence than in the absence of shrubs in year two. This may have been caused by a priming effect (Fontaine et al. 2004): warming was found to increase shrub photosynthetic rates in the same experiment (Ward et al. 2013), which may have resulted in enhanced $\mathrm{C}$ inputs to the soil. Evidence from other studies in the same or similar environments indicates that some ecosystem properties linked to decomposition, such as gross respiration and availability of DOC and DON concentrations, do increase relatively quickly in response to warming (Dorrepaal et al. 2009, Bragazza et al. 2013, Jassey et al. 2013, Ward et al. 2013). Together with our results, this suggests that warming effects on decomposition may become stronger with time, and therefore have important longer-term consequences for decomposition processes in these ecosystems (Dorrepaal et al. 2009, Briones et al. 2010).

\section{Conclusion}

In conclusion, our findings show that vegetation functional group removal exerted stronger effects than a $1^{\circ} \mathrm{C}$ experimental warming on short-term litter decomposition, soil biota, and rates of soil $\mathrm{N}$ mineralization, especially during the second year of decomposition. This highlights an important role of vegetation change, which is occurring in peatlands as a result of various global change drivers, in regulating rates of decomposition in peatlands. The effects of vegetation are seen through both live plant effects and litter, which together influence the composition of belowground communities and rates of nutrient cycling. Our study adds to growing experimental evidence that the effects of vegetation composition can be more important than abiotic factors in controlling decomposition (Cornelissen et al. 2007, Aerts et al. 2012, Hooper et al. 2012), and additionally shows that these effects can be via live vegetation as well as through differences in the quality of litter. Our findings highlight the need to widen the focus of global change studies into peatland carbon cycling, to include vegetation as well as climate change when predicting the future carbon storage potential of these ecosystems.

\section{ACKNOWLEDGMENTS}

This research was supported by a Natural Environment Research Council (NERC) EHFI grant (NE/E011594/1) awarded to R. D. Bardgett and N. J. Ostle. We thank colleagues from Centre for Ecology and Hydrology $(\mathrm{CEH})$ Lancaster and Lancaster University for help in setting up the field experiment and to Amy Valach and Emily Bottoms for help in sorting the litter. We also thank Natural England and the Environmental Change Network, CEH Lancaster for site access and weather data.

\section{Literature Cited}

Aerts, R. 2006. The freezer defrosting: global warming and litter decomposition rates in cold biomes. Journal of Ecology 94:713-724.

Aerts, R., T. V. Callaghan, E. Dorrepaal, R. S. P. van Logtestijn, and J. H. C. Cornelissen. 2012. Seasonal climate manipulations have only minor effects on litter decomposition rates and $\mathrm{N}$ dynamics but strong effects on litter $\mathrm{P}$ dynamics of sub-arctic bog species. Oecologia 170:809-819.

Averill, C., B. L. Turner, and A. C. Finzi. 2014. Mycorrhizamediated competition between plants and decomposers drives soil carbon storage. Nature 505:543-545.

Ayres, E., H. Steltzer, S. Berg, and D. H. Wall. 2009. Soil biota accelerate decomposition in high-elevation forests by specializing in the breakdown of litter produced by the plant species above them. Journal of Ecology 97:901-912.

Bardgett, R. D. 2005. The biology of soil. A community and ecosystem approach. First edition. Oxford University Press, Oxford, UK. 
Bardgett, R. D., C. Freeman, and N. J. Ostle. 2008. Microbial contributions to climate change through carbon cycle feedbacks. ISME Journal, Multidisciplinary Journal of Microbial Ecology 2:805-814.

Bardgett, R. D., and D. A. Wardle. 2010. Abovegroundbelowground linkages: biotic interactions, ecosystem processes, and global change. Oxford University Press, Oxford, UK.

Bobbink, R., et al. 2010. Global assessment of nitrogen deposition effects on terrestrial plant diversity: a synthesis. Ecological Applications 20:30-59.

Bokhorst, S., A. Huiskes, P. Convey, B. J. Sinclair, M. Lebouvier, B. Van de Vijver, and D. H. Wall. 2011. Microclimate impacts of passive warming methods in Antarctica: implications for climate change studies. Polar Biology 34:1421-1435.

Bragazza, L., A. Buttler, A. Siegenthaler, and E. A. D. Mitchell. 2009. Plant litter decomposition and nutrient release in peatlands. Pages 99-110 in A. J. Baird, X. Comas, L. D. Slater, L. R. Belyea, and A. S. Reeve, editors. Carbon cycling in northern peatlands. American Geophysical Union, Washington, D.C., USA.

Bragazza, L., J. Parisod, A. Buttler, and R. D. Bardgett. 2013. Biogeochemical plant-soil microbe feedback in response to climate warming in peatlands. Nature Climate Change 3:273277.

Briones, M. J. I., M. H. Garnett, and P. Ineson. 2010. Soil biology and warming play a key role in the release of 'old C' from organic soils. Soil Biology and Biochemistry 42:960-967.

Briones, M. J. I., P. Ineson, and A. Heinemeyer. 2007. Predicting potential impacts of climate change on the geographical distribution of enchytraeids: a meta-analysis approach. Global Change Biology 13:2252-2269.

Briones, M. J. I., P. Ineson, and T. G. Piearce. 1997. Effects of climate change on soil fauna; responses of enchytraeids, Diptera larvae and tardigrades in a transplant experiment. Applied Soil Ecology 6:117-134.

Briones, M. J. I., P. Ineson, and J. Poskitt. 1998. Climate change and Cognettia sphagnetorum: effects on carbon dynamics in organic soils. Functional Ecology 12:528-535.

Buchanan, G. M., M. C. Grant, R. A. Sanderson, and J. W. Pearce-Higgins. 2006. The contribution of invertebrate taxa to moorland bird diets and the potential implications of landuse management. Ibis 148:615-628.

Cardinale, B. J., et al. 2012. Biodiversity loss and its impact on humanity. Nature 486:59-67.

Carrera, N., M. E. Barreal, P. P. Gallego, and M. J. I. Briones. 2009. Soil invertebrates control peatland $C$ fluxes in response to warming. Functional Ecology 23:637-648.

Cole, L., R. D. Bardgett, P. Ineson, and P. J. Hobbs. 2002. Enchytraeid worm (Oligochaeta) influences on microbial community structure, nutrient dynamics and plant growth in blanket peat subjected to warming. Soil Biology and Biochemistry 34:83-92.

Cornelissen, J. H. C., et al. 2007. Global negative vegetation feedback to climate warming responses of leaf litter decomposition rates in cold biomes. Ecology Letters 10:619-627.

Craine, J. M., N. Fierer, and K. K. McLauchlan. 2010. Widespread coupling between the rate and temperature sensitivity of organic matter decay. Nature Geoscience 3: 854-857.

de Vries, F. T., et al. 2013. Soil food web properties explain ecosystem services across European land use systems. Proceedings of the National Academy of Sciences USA 110:14296-14301.

Diaz, S., A. J. Symstad, F. S. Chapin, III, D. A. Wardle, and L. F. Huenneke. 2003. Functional diversity revealed by removal experiments. Trends in Ecology and Evolution 18: $140-146$.

Dise, N. B. 2009. Peatland response to global change. Science 326:810-811.

Dorrepaal, E., J. H. C. Cornelissen, and R. Aerts. 2007. Changing leaf litter feedbacks on plant production across contrasting sub-arctic peatland species and growth forms. Oecologia 151:251-261.

Dorrepaal, E., S. Toet, R. S. P. van Logtestijn, E. Swart, M. J. van de Weg, T. V. Callaghan, and R. Aerts. 2009. Carbon respiration from subsurface peat accelerated by climate warming in the subarctic. Nature 460:616-619.

Eisenhauer, N., T. Dobies, S. Cesarz, S. E. Hobbie, R. J. Meyer, K. Worm, and P. B. Reich. 2013. Plant diversity effects on soil food webs are stronger than those of elevated $\mathrm{CO}_{2}$ and $\mathrm{N}$ deposition in a long-term grassland experiment. Proceedings of the National Academy of Sciences USA 110: 6889-6894.

Fenner, N., and C. Freeman. 2011. Drought-induced carbon loss in peatlands. Nature Geoscience 4:895-900.

Fontaine, S., G. Bardoux, L. Abbadie, and A. Mariotti. 2004. Carbon input to soil may decrease soil carbon content. Ecology Letters 7:314-320.

Freeman, C., N. Ostle, and H. Kang. 2001. An enzymic 'latch' on a global carbon store. Nature 409:149.

Freschet, G. T., R. Aerts, and J. H. C. Cornelissen. 2012. Multiple mechanisms for trait effects on litter decomposition: moving beyond home-field advantage with a new hypothesis. Journal of Ecology 100:619-630.

Gardes, M., and T. D. Bruns. 1993. ITS primers with enhanced specificity for basidiomycetes - application to the identification of mycorrhizae and rusts. Molecular Ecology 2:113-118.

Gorham, E. 1991. Northern peatlands: role in the carbon cycle and probable responses to climatic warming. Ecological Applications 1:182-195.

Grace, J., and T. C. Marks. 1978. Physiological aspects of bog production at Moor House. Pages 38-51 in O. W. Heal and D. F. Perkins, editors. Production ecology of British moors and montane grasslands. Springer-Verlag, New York, New York, USA.

Griffiths, R. I., A. S. Whiteley, A. G. O'Donnell, and M. J. Bailey. 2000. Rapid method for coextraction of DNA and RNA from natural environments for analysis of ribosomal DNA- and rRNA-based microbial community composition. Applied and Environmental Microbiology 66:5488-5491.

Hattenschwiler, S., and P. M. Vitousek. 2000. The role of polyphenols in terrestrial ecosystem nutrient cycling. Trends in Ecology and Evolution 15:238-243.

Heal, O. W., and R. A. H. Smith. 1978. The Moor House programme: introduction and site description. Pages 1-16 in O. W. Heal and D. F. Perkins, editors. Production ecology of British moors and montane grasslands. Springer-Verlag, New York, New York, USA.

Hobbie, S. E. 1992. Effects of plant species on nutrient cycling. Trends in Ecology and Evolution 7:336-339.

Hooper, D. U., E. C. Adair, B. J. Cardinale, J. E. K. Byrnes, B. A. Hungate, K. L. Matulich, A. Gonzalez, J. E. Duffy, L. Gamfeldt, and M. I. O'Connor. 2012. A global synthesis reveals biodiversity loss as a major driver of ecosystem change. Nature 486:105-129.

Hooper, D. U., et al. 2005. Effects of biodiversity on ecosystem functioning: a consensus of current knowledge. Ecological Monographs 75:3-35.

Jassey, V. E. J., et al. 2013. Above- and belowground linkages in sphagnum peatland: climate warming affects plantmicrobial interactions. Global Change Biology 19:811-823.

Jonsson, M., and D. A. Wardle. 2008. Context dependency of litter-mixing effects on decomposition and nutrient release across a long-term chronosequence. Oikos 117:1674-1682.

Kardol, P., M. A. Cregger, C. E. Campany, and A. T. Classen. 2010. Soil ecosystem functioning under climate change: plant species and community effects. Ecology 91:767-781.

Kareiva, P., S. Watts, R. McDonald, and T. Boucher. 2007. Domesticated nature: shaping landscapes and ecosystems for human welfare. Science 316:1866-1869.

Lane, D. J. 1991. 16S/23S rRNA sequencing. Pages 115-175 in E. Stackenbrandt and M. Goodfellow, editors. Nucleic acid 
techniques in bacterial systematics. Wiley, New York, New York, USA.

Latter, P. M., G. Howson, D. M. Howard, and W. A. Scott. 1998. Long-term study of litter decomposition on a Pennine peat bog: which regression? Oecologia 113:94-103.

Lindsay, R. 2010. Peatbogs and carbon: a critical synthesis. Royal Society for the Protection of Birds, Scotland, UK. http://www.rspb.org.uk/Images/Peatbogs_and_carbon_ tcm9-255200.pdf

Marchesi, J. R., T. Sato, A. J. Weightman, T. A. Martin, J. C. Fry, S. J. Hiom, D. Dymock, and W. G. Wade. 1998. Design and evaluation of useful bacterium-specific PCR primers that amplify genes coding for bacterial 16S rRNA. Applied and Environmental Microbiology 64:795-799.

Marion, G. M., et al. 1997. Open-top designs for manipulating field temperature in high-latitude ecosystems. Global Change Biology 3:20-32.

O'Connor, F. B. 1955. Extraction of enchytraeid worms from a coniferous forest soil. Nature 175:815-816.

Oksanen, J., F. G. Blanchet, R. Kindt, P. Legendre, R. G. O'Hara, G. L. Simpson, P. Solymos, M. H. M. Stevens, and H. Wagner. 2013. Vegan: community ecology package. R package version 2.0-10. http://cran.at.r-project.org/web/packages/ vegan/index.html

Orwin, K. H., M. U. F. Kirschbaum, M. G. St John, and I. A. Dickie. 2011. Organic nutrient uptake by mycorrhizal fungi enhances ecosystem carbon storage: a model-based assessment. Ecology Letters 14:493-502.

Orwin, K. H., and N. J. Ostle. 2012. Moss species effects on peatland carbon cycling after fire. Functional Ecology 26: 829-836.

Papanikolaou, N., A. J. Britton, R. C. Helliwell, and D. Johnson. 2010. Nitrogen deposition, vegetation burning and climate warming act independently on microbial community structure and enzyme activity associated with decomposing litter in lowalpine heath. Global Change Biology 16:3120-3132.

Pearce-Higgins, J. W. 2010. Using diet to assess the sensitivity of northern and upland birds to climate change. Climate Research 45:119-130.

$\mathrm{R}$ Development Core Team. 2013. R version 3.0.2. R: a language and environment for statistical computing. $\mathrm{R}$ Foundation for Statistical Computing, Vienna, Austria. http://www.R-project.org/

Read, D. J., J. R. Leake, and J. Perez-Moreno. 2004. Mycorrhizal fungi as drivers of ecosystem processes in heathland and boreal forest biomes. Canadian Journal of Botany 82:1243-1263.

Read, D. J., and J. Perez-Moreno. 2003. Mycorrhizas and nutrient cycling in ecosystems - a journey towards relevance? New Phytologist 157:475-492.

Rinnan, R., A. Michelsen, E. Baath, and S. Jonasson. 2007. Fifteen years of climate change manipulations alter soil microbial communities in a subarctic heath ecosystem. Global Change Biology 13:28-39.

Rodwell, J. S. 1991. British plant communities. Volume 2. Mires and heaths. Cambridge University Press, Cambridge, UK.

Ross, D. J. 1992. Influence of sieve mesh size on estimates of microbial carbon and nitrogen by fumigation-extraction procedures in soils under pasture. Soil Biology and Biochemistry $24: 343-350$.

Rydin, H., and J. Jeglum. 2006. The biology of peatlands. Oxford University Press, Oxford, UK.
St John, M. G., K. H. Orwin, and I. A. Dickie. 2011. No 'home' versus 'away' effects of decomposition found in a grasslandforest reciprocal litter transplant study. Soil Biology and Biochemistry 43:1482-1489.

Stevens, C. J., et al. 2010. Nitrogen deposition threatens species richness of grasslands across Europe. Environmental Pollution 158:2940-2945.

Thomson, B. C., N. Ostle, N. McNamara, M. J. Bailey, A. S. Whiteley, and R. I. Griffiths. 2010. Vegetation affects the relative abundances of dominant soil bacterial taxa and soil respiration rates in an upland grassland soil. Microbial Ecology 59:335-343.

Thormann, M. N. 2006. Diversity and function of fungi in peatlands: a carbon cycling perspective. Canadian Journal of Soil Science 86:281-293.

Trinder, C. J., R. R. E. Artz, and D. Johnson. 2008. Contribution of plant photosynthate to soil respiration and dissolved organic carbon in a naturally recolonising cutover peatland. Soil Biology and Biochemistry 40:1622-1628.

Vitousek, P. M., H. A. Mooney, J. Lubchenco, and J. M. Melillo. 1997. Human domination of Earth's ecosystems. Science 277:494-499.

Vivanco, L., and A. T. Austin. 2008. Tree species identity alters forest litter decomposition through long-term plant and soil interactions in Patagonia, Argentina. Journal of Ecology 96: $727-736$.

Walker, M. D., et al. 2006. Plant community responses to experimental warming across the tundra biome. Proceedings of the National Academy of Sciences USA 103:1342-1346.

Ward, S. E., R. D. Bardgett, N. P. McNamara, J. K. Adamson, and N. J. Ostle. 2007. Long-term consequences of grazing and burning on northern peatland carbon dynamics. Ecosystems 10:1069-1083.

Ward, S. E., N. J. Ostle, N. P. McNamara, and R. D. Bardgett. 2010. Litter evenness influences short-term peatland decomposition processes. Oecologia 164:511-520.

Ward, S. E., N. J. Ostle, S. Oakley, H. Quirk, P. A. Henrys, and R. D. Bardgett. 2013. Warming effects on greenhouse gas fluxes in peatlands are modulated by vegetation composition. Ecology Letters 16:1285-1293.

Ward, S. E., N. J. Ostle, S. Oakley, H. Quirk, A. Stott, P. A. Henrys, W. A. Scott, and R. D. Bardgett. 2012. Fire accelerates assimilation and transfer of photosynthetic carbon from plants to soil microbes in a northern peatland. Ecosystems 15:1245-1257.

Wardle, D. A., R. D. Bardgett, J. N. Klironomos, H. Setala, W. H. van der Putten, and D. H. Wall. 2004. Ecological linkages between aboveground and belowground biota. Science 304:1629-1633.

Wardle, D. A., and O. Zackrisson. 2005. Effects of species and functional group loss on island ecosystem properties. Nature 435:806-810.

Weedon, J. T., G. A. Kowalchuk, R. Aerts, J. van Hal, R. van Logtestijn, N. Tas, W. F. M. Roling, and P. M. van Bodegom. 2012. Summer warming accelerates sub-arctic peatland nitrogen cycling without changing enzyme pools or microbial community structure. Global Change Biology 18:138-150.

White, T. J., T. D. Bruns, S. B. Lee, and J. W. Taylor. 1990. Rapid characterization of ectomycorrhizae using RFLP pattern of their PCR amplified-ITS. Pages 315-322 in M. A. Innis, D. H. Gelfand, J. J. Sninsky, and T. J. White, editors. PCR protocols: a guide to methods and applications. Academic Press, San Diego, California, USA.

\section{Supplemental Material}

\section{Ecological Archives}

Appendices A-C are available online: http://dx.doi.org/10.1890/14-0292.1.sm 